\author{
Paweł Dziadul \\ (Uniwersytet im. A. Mickiewicza w Poznaniu)
}

\title{
Kultura serbska w okresie panowania osmańskiego. Płaszczyzny adaptacji - płaszczyzny alienacji
}

\author{
Serbian Culture During the Ottoman Period. \\ Levels of Adaptation - Levels of Alienation
}

\section{STRESZCZENIE}

Artykuł dotyczy kultury serbskiej i jej różnych płaszczyzn w okresie osmańskim. Skoncentrowano się zwłaszcza na okresie początkowym panowania osmańskiego, w którym Imperium Osmańskie przejawiało specyficzny pragmatyczny stosunek do chrześcijańskich poddanych, absorbując ich lokalne praktyki i wzorce społeczno-kulturowe. Imperium Osmańskie adaptowało oraz włączało je we własne struktury feudalno-administracyjne i społeczno-polityczne, nawet jeśli były sprzeczne z islamem i prawem szariatu. Turcy osmańscy dążyli przede wszystkim do zachowania politycznej, kulturowej i społecznej ciągłości. W artykule skupiono się również na zjawisku kulturowego i religijnego synkretyzmu, który poddano analizie w relacji do zjawisk związanych $\mathrm{z}$ tendencjami antysynkretycznymi. Głównym zaś celem było ukazanie wpływu kultury serbskiej na proces konstruowania wspólnej multietnicznej, multikonfesyjnej i multijęzykowej kultury rozwijającej się w osmańskiej Rumelii.

Słowa kluczowe: kultura serbska, okres osmański, wpływ kulturowy, synkretyzm, mniejszość

Podbój i inkorporacja ziem serbskich przez Imperium Osmańskie to proces złożony, wymagający uwzględnienia wielu aspektów historyczno-politycznych i społeczno-kulturowych. Oceniając specyfikę kultury serbskiej w okresie osmańskiej dominacji, najczęściej zwracano uwagę na jej izolacjonizm, odporność na obce wpływy, charakterystyczne "skostnienie", niezmienność etc. Do pewnego stopnia jest to prawda, bowiem kultura serbska była immanentnie związana z prawosławiem oraz Cerkwią a ta przez swój tradycjonalizm i hermetyzm skutecznie uodparnia- 


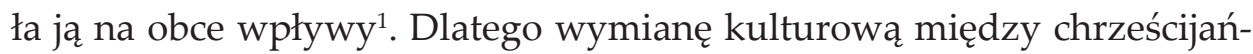
ską kulturą serbską a islamską osmańską skutecznie utrudniał głównie element konfesyjny. Jednak kultura serbska (podobnie jak inne kultury ludów podbitych przez Imperium Osmańskie) pod wpływem dominującej kultury osmańskiej ulegała różnym przeobrażeniom, i podobnie na kulturę osmańską oddziaływała kultura serbska. Niestety, rekonstrukcję złożonych procesów kulturowych utrudniają pewne schematy interpretacyjne, skróty myślowe czy mity produkowane przez krystalizujące się od końca XVIII oraz w XIX w. ideologie i mitologie narodów bałkańskich, które po długiej walce o niezależność usiłowały wymazać najdrobniejsze ślady osmańskiej obecności. Jednym z głównych mitów jest sam obraz osmańskiego panowania naznaczony, jak podkreślano, rzeziami, prześladowaniami i powszechnym uciskiem chrześcijan². Imperium Osmańskie było państwem muzułmańskim, którego podstawę bytową determinował pierwiastek militarny i konfesyjny. Fundament prawny Imperium - szariat - ewokował częściowo politykę dyskryminacyjną w stosunku do niewiernych, jednocześnie jednak gwarantował określone przywileje dla niemuzułmańskich poddanych sułtana, pewien rodzaj protekcji i ochrony. Dlatego Imperium Osmańskie odznaczało się niewątpliwie większą tolerancją w XV czy XVI w. niż wiele krajów Europy Zachodniej w tym okresie, lecz tolerancja nie oznaczała równości. Chrześcijanie objęci byli specyficznymi prawami restrykcyjnymi (takimi jak: zakaz jazdy konno, noszenia broni, budowy i remontu cerkwi bez pozwolenia). Ponadto znajdowali się w specjalnym systemie podatkowym (np. płacili podatek pogłówny cizye) oraz obowiązywał ich tzw. devşirme - „danina krwi”3. Zgodnie z muzułmańską wizją świata ziemie i ludy znajdujące się poza władzą islamu (dar al-harb) podlegały prawom dżihadu, jednak celem Turków nie było ich unicestwienie, lecz podbój oraz dominacja z korzyścią dla islamu. Objęte prawem protekcji i ochrony podbite ludy (dhimmi) innego wyznania (chodzi tu nie o pogan, których według Koranu należy nawracać lub zwalczać, lecz o ahl al-kitâb, czyli „ludy Księgi”4) były dość łaskawie trakto-

${ }^{1}$ L. Hadrovics, Srpski narod i njegova Crkva pod turskom vlašću, prev. M. Kovačević, Zagreb 2000, s. 17.

${ }^{2}$ D. Kołodziejczyk, The "Turkish yoke" revisited: the Ottoman Non-Muslim Subjects between Loyalty, Alienation and Riot, "Acta Poloniae Historica” 2006, 93, s. 180. Zob. też M. Kul, Izkustvo i obščestvo v Bâlgarija prez tureckija period, przeł. R. Gradeva, Sofija 2002, s. 25-41.

${ }^{3}$ Zob.: L. Stavrianos, The Balkans since 1453, New York 2000, s. 105; P. Sugar, Southeastern Europe under Ottoman Rule 1354-1804, Seattle-London 1977, s. 31-59.

${ }_{4}^{4}$ „Walczcie z tymi spośród Ludu Księgi, którzy nie wierzą w Allacha, ani w Dzień Ostatni, ani nie uważają za nieprawe tego, co Allach i Jego Posłaniec ogłosili nieprawym, aż do czasu, gdy zapłacą należność, uznając to za łaskę i uznają swe podporządkowanie" (Koran 9: 29). 
wane i otrzymywały odpowiednie miejsce w hierarchii ${ }^{5}$. Kościół prawosławny uzyskał od władzy osmańskiej szeroką autonomię ${ }^{6}$, jednak patriarcha uzależniony był od podmiotu władzy związanego z obcą kultura, od wydawanych przez sułtanów beratów, dlatego będąca wcześniej podstawą bytu polityczno-religijnego państwa serbskiego idea diarchii w okresie osmańskim musiała ulec deprecjacji. Państwo osmańskie generalnie nie ingerowało w życie codzienne ani wierzenia ludności chrześcijańskiej ${ }^{7}, \dot{z} y-$ jącej często w odizolowanych komórkach rodowo-plemiennych (zadruga).

$\mathrm{Z}$ uwagi, że tradycja jest czymś dynamicznym, niestałym, podatnym na ideologiczną i polityczną „obróbkę", należy odróżnić ją od pojęcia "dziedzictwa kulturowego", które powinno się traktować jako cały dorobek kulturowy pozostawiony przez poprzednie generacje ${ }^{8}$. Tradycja zaś to fragment dziedzictwa "wybrany" przez wspólnotę, będącą w danym momencie historycznym „konstruktorem tożsamości”. Innymi słowy, jest to grupa, której wizja historii jest propagowana przez „oficjalny” nurt kultury. Zatem dziedzictwo jest dziedziczone, przekazywane mimowolnie przez proces dziejowy, natomiast tradycja jest „wybierana”, konstruowana, uznana za coś szczególnie cennego, wartego zachowania i kultywowania. Procesy te powiązane są z faktem, iż każda kultura wyznacza swój obszar w ramach całości, której jest częścią. Całość ta konotuje te elementy (wzorce, wartości, idee etc.), które pochodzą od różnych, często sąsiednich, zbiorowości. Każda kultura ustosunkowuje się do nich przez ich akceptację bądź odrzucenie, co warunkowane jest w dużej mierze stosunkiem do kultury obcej i jej uniwersum symbolicznego. Stosunek ten może generować sferę alienacji (odrzucenie, ignorancja) bądź sferę adaptacji czy uniwersalizacji (afiliacja, przyswojenie) ${ }^{9}$. Nośnikiem alternatywnego uniwersum symbolicznego, rozumianego jako kompleks tradycji integrujący różne obszary znaczenia i ujmujący porządek instytucjonalny jako symboliczną całość ${ }^{10}$, była orientalna, islamska kultura osmańska, która stała się zagrożeniem dla chrześcijańskich kultur bałkańskich, w tym kultury serbskiej. W wyniku konfrontacji z odmiennym, zagrażającym uniwersum własne uniwersum musi zostać symbolicznie uprawomocnione, aby tradycja została podtrzymana. Niekiedy w wyniku tego typu wy-

${ }^{5}$ H. Inalcik, Imperium Osmańskie: epoka klasyczna 1300-1600, przeł. J. Hunia, Kraków 2006, s. 51.

${ }^{6}$ T. Katić, Serbia under the Ottoman Rule, „Österreichische Osthefte” 2005, 47, s. 147.

${ }^{7}$ B. Jelavich, Historia Bałkanów - wiek XVIII i XIX, t. 1, przeł. J. Polak, K. Salawa, Kraków 2005, s. 60-61.

${ }^{8}$ J. Szacki, Tradycja. Przeglad problematyki, Warszawa 1971, s. 124-146.

${ }^{9}$ A. Kłoskowska, Kultury narodowe u korzeni, Warszawa 2005, s. 36-37.

${ }^{10}$ P.L. Berger, T. Luckmann, Społeczne tworzenie rzeczywistości. Traktat z socjologii wiedzy, przeł. J. Niżnik, Warszawa 2010, s. 141. 
zwań własne uniwersum symboliczne ulega modyfikacji oraz rozszerzeniu w celu uwypuklenia jego wyższości i supremacji ${ }^{11}$. Niewątpliwie kontakt z odmiennymi społecznościami i kulturami stanowi jeden z kluczowych determinantów tożsamości, która generalnie kształtuje się w społecznych interakcjach, w konfrontacji z „innością”, poprzez procesy upodabniania bądź różnicowania ${ }^{12}$.

Historyczne doświadczenie osmańskiego panowania jest bez wątpienia jednym z konstytutywnych aspektów serbskiej tożsamości zbiorowej, sytuując się raczej w ramach pamięci negatywnej, konotującej walkę wyzwoleńczą ucisk, męczeństwo. Uruchomiony w XIX w. projekt narodowy, determinujący proces konstruowania „pożądanej” tradycji i tożsamości zbiorowej, uczynił z doświadczenia osmańskiej dominacji, jak już wspomniano, rodzaj specyficznego mitu. Absorbował on wszystkie negatywne, niechciane, niepasujące do promowanego obrazu tradycji elementy kulturowe powiązane głównie $\mathrm{z}$ takimi zagadnieniami, jak barbaryzacja, ruralizacja czy agraryzacja zarówno Serbii, jak i całych Bałkanów. Interesuje nas jednak funkcjonowanie kultury serbskiej w ramach dominującej kultury osmańskiej, przede wszystkim wpływ kultury serbskiej na proces konstruowania wspólnej multietnicznej, multikonfesyjnej, multijęzykowej kultury, rozwijającej się w europejskich prowincjach Imperium Osmańskiego (Rumelia).

Osmańskie panowanie na Bałkanach postrzegane było często przez pryzmat wyekscerpowanej z kontekstu rzeczywistości jednego okresu, np. XIX w. czy XVII w., co ewokuje mylne wrażenie historyczno-kulturowej czy polityczno-społecznej jednolitości, względnie synchronicznego constans. Analizując rzeczywistość kulturowa, polityczną lub społeczną okresu osmańskiego, należy niewątpliwie uwzględnić synchroniczną oraz diachroniczną zmienność, różnorodność regionalna, a także wymiar wertykalny i horyzontalny osmańskiego systemu feudalno-administracyjnego. Wbrew utartym schematom, wyobrażeniom czy skrótom myślowym nowy porządek pax Ottomana nie zniszczył zastanych na podbitych terenach struktur społeczno-kulturowych, lecz część z nich została inkorporowana do nowego systemu. Pierwszy etap osmańskich podbojów i panowania na Bałkanach od połowy XIV w. do połowy XVI w. jest zasadniczo odmienny od kolejnych. Imperium Osmańskie odznaczało się wówczas specyficznym pragmatyzmem, absorbując lokalne praktyki, formy, wzorce kulturowe, włączając je we własne struktury, nawet jeśli były sprzecz-

${ }^{11}$ Ibidem, s. $158-159$.

${ }^{12}$ M. Golka, Konstruowanie tożsamości-czynniki społeczno-kulturowe, „Ruch Prawniczy, Ekonomiczny i Socjologiczny" 2012, 74, 2, s. 215. 
ne z islamem i prawem szariatu. Turcy osmańscy bowiem dążyli do zachowania ciągłości kulturowej, politycznej i społecznej. Za ustanowienie i utrzymanie rządów nad ogromnymi masami chrześcijan bałkańskich w dużej mierze odpowiadała osmańska praktyka polityczna, tzw. istimâlet. Była to tolerancyjna, ugodowa koncepcja ustępstw względem ludności niemuzułmańskiej, stosowana w celu uzyskania ich przychylności, poparcia i akceptacji (objawiała się przykładowo w formie zmniejszania należności podatkowych względem państwa czy ułatwienia w systemie dziedziczenia ziemi ${ }^{13}$. Z tego powodu być może król Bośni Stefan Tomašević (1461-1463) w swym posłaniu do papieża Piusa II pisał, że miejscowe chłopstwo traktowało Turków osmańskich jak wyzwolicieli, nie wspomagając swych lokalnych panów. Turcy obiecywali im swobodę w zamian za przejście na ich stronę, żalił się król ${ }^{14}$.

Zgodnie z osmańską polityką adaptacji lokalnych struktur, praktyk czy wzorców społeczno-politycznych i kulturowych bizantyńska oraz bałkańska arystokracja były w pragmatyczny sposób wykorzystywane przez Turków osmańskich ${ }^{15}$. Kilku Serbów w szczególny sposób zapisało się w historii Imperium Osmańskiego, zajmując wysokie stanowiska i wpływając w istotny sposób na osmańską politykę czy kulturę. Wielu członków bizantyńskiej, bałkańskiej oraz szczególnie nas interesującej serbskiej arystokracji zostało wielkimi wezyrami (których kariera związana była niekiedy z systemem devşirme), bowiem Turcy potrzebowali $\mathrm{w}$ ustanawianym na podbitych terenach systemie administracyjnym oraz politycznym ludzi znających język, kulturę i lokalne realia. Wśród nich warto wymienić pochodzącego z bizantyńsko-serbskiej rodziny arystokratycznej (tesalijska linia serbskich despotów; brat Michała Angelovicia z Novego Brda) Mahmuda Paszę Angelovicia czy pochodzącego z bośniackiej szlachty Ahmeda Paszę Hercegovicia (wcześniej Stefan Hercegović; syn wojewody/hercega św. Sawy Stefana Vukčicia Kosača) ${ }^{16}$. Mimo przyjęcia nowej wiary, kultury czy imion członkowie byłej bizantyńskiej i bałkańskiej arystokracji byli w pełni świadomi swej chrześcijańskiej przeszłości oraz utrzymywali bliskie relacje ze swymi chrześcijańskimi rodzinami. Należy pamiętać, że dopiero później powstał stygmat „poturczeńca”, renegata i zdrajcy narodowego. Wśród drugiej grupy

${ }^{13}$ H. Lowry, The Nature of the Early Ottoman State, Albany 2003, s. 101-103; H. Inalcik, Ottoman Methods of Conquest, ",Studia Islamica” 1954, 2, s. 112.

${ }_{14}$ Pismo bosanskog kralja Stepana Tomaševića rimskom papi Piu II 1461 god., w: O etnogenezi Bošnjaka, red. H. Zoranić, Sarajevo 2009, s. 393.

15 S. Vryonis, The Byzantine Legacy and Ottoman Forms, "Dumbarton Oaks Papers" 1969/1970, 23/24, s. 269-272.

${ }^{16}$ H. Lowry, op. cit., s. 117. 
wielkich wezyrów, którzy nie mieli arystokratycznego pochodzenia, należy wymienić przede wszystkim Mehmeda Paszę Sokolovicia, pełniącego swą funkcję za panowania aż trzech sułtanów. Pomimo konwersji wyznaniowej i islamskiego wychowania nigdy nie zapomniał o swej serbskiej, chrześcijańskiej przeszłości. Dzięki jego inicjatywie restaurowano serbski patriarchat w Peci w $1557 \mathrm{r}$.

Na proces formowania wspólnej „rumelijskiej” kultury w sposób szczególny wpływały też kobiety chrześcijanki. Serbkami, które zapisały się w historii i kulturze Imperium Osmańskiego były przede wszystkim córka księcia Lazara Hrebeljanovicia i księżnej Milicy - Olivera, która poślubiła (w 1390/1391) sułtana Bajazyda I oraz córka despoty serbskiego Đurđa Brankovicia, żona Murada II (od 1436) - Mara. Polityka matrymonialna Imperium przypominała tę bizantyńską i opierała się na analogicznych zasadach. W ogóle warto podkreślić, iż w przededniu tureckiego podboju, w pierwszej połowie XV w. na dworze serbskich despotów istniało silne turkofilskie ugrupowanie, którego wyrazem dążeń były właśnie małżeństwa serbskich arystokratek z sułtanami czy udział wojsk serbskich w osmańskich kampaniach militarnych, co Konstantyn (Filozof) Kostenecki w Żywocie despoty Stefana Lazarevicia tłumaczy w kategoriach dziejowego przymusu (,Jер сви ови беху са Измаиљћанима, ако и не по [својој] вољи, а оно по нужди"17), uwypuklając nadrzędną rolę kodu feudalnego i etyki rycerskiej, którymi w pierwszej kolejności powinien kierować się idealny władca. Chrześcijańskie małżonki sułtanów, które swobodnie mogły wyznawać swą religię, oddziaływały na politykę sułtanów względem prawosławia i Cerkwi oraz mogły wprowadzać chrześcijańskie obyczaje na sułtańskim dworze. Żony sułtanów były fundatorkami i donatorkami cerkwi czy monastyrów. W tej kwestii szczególnie zasłynęła Mara, której wpływ na negocjacje polityczne oraz obsadę stanowisk cerkiewnych w Imperium był znany ${ }^{18}$. Zasłynęła jako opiekunka i hojny darczyńca centrów kultu, szczególnie na Górze Athos (Chilandar, monastyr św. Pawła). W ogóle warto podkreślić, iż mieszane małżeństwa (chodzi o chrześcijańskie małżonki muzułmanów; małżeństwa muzułmanek z chrześcijanami były zabronione) oraz obecność chrześcijanek w muzułmańskich haremach skutecznie przyczyniały się do powstania zjawiska synkretyzmu kulturowego i religijnego ${ }^{19}$.

${ }^{17}$ Konstantin Filozof, Povest o slovima (Skazanije o pismeneh). Žitije despota Stefana Lazarevića, red. G. Jovanović, Beograd 1989, s. 90.

${ }^{18}$ I. Czamańska, Chrześsijańskie małżonki suttanów tureckich. Małżeństwa polityczne w Imperium Osmańskim XIV i XV wieku, „Balcanica Posnaniensia. Acta et Studia” 2013, 20, s. 61.

${ }^{19}$ Zob. H. Lowry, op. cit., s. 119. 
Po 1459 r. istotną rolę $\mathrm{w}$ finansowaniu, wspieraniu czy fundowaniu/ restaurowaniu prawosławnych cerkwi i monastyrów ${ }^{20}$ odgrywali również chrześcijańscy Serbowie, którzy w początkowym okresie osmańskiego panowania zostali włączeni do wyższych klas - askeri osmańskiej drabiny feudalnej, np. chrześcijańscy spahisi $i^{21}$. Była to feudalna kasta wojowników ciężkiej jazdy (kawalerzyści), którzy za swą służbę w osmańskiej armii otrzymywali posiadłości lenne (timar). Generalnie, teoria o likwidacji bałkańskich, w tym serbskich, elit w okresie osmańskim nie jest do końca prawdziwa. Lokalne struktury dynastyczne oraz wyższa arystokracja upadły, jednak część średniej i drobnej szlachty zaczęła funkcjonować w osmańskim systemie feudalno-administracyjnym ${ }^{22}$. Wraz z zanikiem starych struktur arystokratycznych rozpoczął się proces (re)konstrukcji nowego, osmańskiego społeczeństwa serbskiego. Wykształcała się nowa serbska „elita” (mająca status askeri), składająca się głównie z chrześcijańskich spahisów, którzy oczywiście nie byli postrzegani w systemie osmańskim jako arystokracja oraz nie byli pełnoprawnymi posiadaczami ziemi ${ }^{23}$. W niektórych rejonach Serbii w początkowym okresie osmańskiej dominacji wśród spahisów przeważali chrześcijanie; przykładowo w sandżaku smederevskim ten stosunek wynosił 85 (chrześcijanie) do 64 (muzułmanie) ${ }^{24}$. W okresie tym doszło również do częściowej „serbizacji” osmańskiej armii. Chrześcijanie, w tym Serbowie, służyli w osmańskich strukturach militarnych ${ }^{25}$ głównie jako (często rekrutowani ze społeczności Wołochów; termin oznaczający różne grupy etniczne w tym okresie) tzw. vojnuci (lp. vojnuk) i martolosi (o roli tych grup militarnych ${ }^{26} \mathrm{w}$ osmańskiej armii wspominał Konstantyn Mihailović w swej

${ }^{20} \mathrm{~Np}$. pełniący funkcję kneza Vlađ Bilić/Bijelić (protoplasta rodu Vlađević/Vlahović) był fundatorem cerkwi św. Lazara we wsi Vlahovići koło Ljubinje, gdzie został pochowany. Spahis Milisav Hrabren (Miloradović) był fundatorem i donatorem monastyru Žitomislić w Hercegowinie oraz cerkwi Przemienienia Pańskiego we wsi Klepci koło Prebilovicy. Generalnie, ród Miloradović był znany z licznych fundacji, np. cerkiew św. Piotra i Pawła w miejscowości Ošanići koło Stoca (wojewoda Radosav, początek XVI w.); cerkiew św. Mikołaja w Trebinju (wojewoda Radoje, 1534), zob. S. Petković, Art and Patronage in Serbia during the Early Period of Ottoman Rule (1450-1600), w: Manzikert to Lepanto. The Byzantine World and the Turks 1071-1571, eds. A. Bryer, M. Ursinus, Birmingham 1985, s. 414.

${ }^{21}$ D. Kołodziejczyk, op. cit., s. 188. S. Petković, op. cit., s. 406.

${ }^{22}$ V. Kursar, Non-Muslim Communal Divisions and Identities in the Early Modern Ottoman Balkans and the Millet System Theory, w: Power and Influence in South-Eastern Europe $16^{\text {th }}-19^{\text {th }}$ Century, eds. M. Baramova, P. Mitev, I. Parev, V. Racheva, Berlin 2013, s. 99-100.

${ }^{23}$ E. Miljković, Who was Rich and who was Poor? Creation of the New Serbian "Elite" in the Serbian 15 $5^{\text {th }}$ Century Society, "Beogradski istorijski glasnik” 2011, 2, s. 130.

${ }^{24}$ O. Zirojević, Srbija pod turskom vlašću 1459-1804, Beograd 2009, s. 35.

${ }^{25}$ Zob. S. Vryonis, op. cit., s. 273.

${ }^{26}$ System funkcjonowania tych grup militarnych istniał wcześniej w średniowiecznej Serbii (vojnuci) i w Bizancjum (martolosi), O. Zirojević, Srbija pod turskom, s. 43. 
Kronice tureckiej) ${ }^{27}$. Vojnuci mogli służyć w armii jako piechurzy lub kawalerzyści, otrzymując ziemie i ulgi podatkowe. Martolosi natomiast wykorzystywani byli częściej jako piechurzy, pogranicznicy lub stróże po$\mathrm{rządku}^{28}$. Mogli otrzymać lenno w postaci timaru, przyjmowali stałą pensję oraz zostali zwolnieni z obciążeń podatkowych ${ }^{29}$.

Kolejną płaszczyzną adaptacji była płaszczyzna językowa. Język serbski bowiem stał się w pewnym momencie ważnym językiem urzędowym europejskich terytoriów Imperium Osmańskiego (Rumelii). W języku serbskim i pismem cyrylickim Wysoka Porta prowadziła korespondencję $^{30} \mathrm{z}$ takimi państwami, jak Węgry, Wołoszczyzna, Mołdawia, Wenecja i Dubrownik (chodzi o tzw. narodni jezik z niewielkim wpływem języka staro-cerkiewno-słowiańskiego; najstarszym serbskim dokumentem oficjalnej osmańskiej korespondencji międzynarodowej jest odnowa traktatu pokojowego między sułtanem Bajazydem II i węgierskim królem Władysławem II z 1498 r.) $)^{31}$. Korzystali z niego zarówno sułtani, wezyrowie, osmańscy lokalni urzędnicy, jak i węgierscy, mołdawscy oraz wołoscy władcy czy magnaci ${ }^{32}$. W tej kwestii za symptomatyczną można uznać prośbę beglerbega Mehmeda Paszy do Andreasa Báthorego, kapitana węgierskiej twierdzy w Temiszwarze, aby wszystkie swe listy redagował po

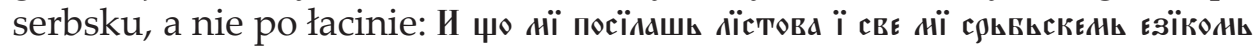
посї^аї, а нє фј४шки ${ }^{33}$. Serbski był głównie językiem dyplomacji, o czym świadczy przykładowo korespondencja Murada II z Republiką Dubrownicka, listy Mehmeda II, Ali Bega, Hamza Bega, Bajazyda II, Selima I czy Sulejmana $\mathrm{II}^{34}$. Fakt wykorzystywania języka serbskiego w osmańskiej korespondencji międzynarodowej oraz dyplomacji związany był ze wspomnianą „serbizacją" osmańskiej administracji i niektórych grup militarnych.

W początkowym okresie mechanizmy osmańskiego prawodawstwa polegały na zachowywaniu regulacji legislacyjnych z poprzednich okre-

27 Pamiętniki Janczara czyli kronika turecka Konstantego z Ostrowicy napisana między $r$. 1496 a 1501, wyd. J. Łoś, Kraków 1912, s. 152.

${ }^{28}$ M. Vasić, Martolosi u jugoslovenskim zemljama pod turskom vladavinom, Sarajevo 2005, s. $87-166$.

${ }^{29}$ H. Inaldžik, Od Stefana Dušana do osmanskog carstva. Hrišćanske spahije u Rumeliji u XV vijeku i njihovo porijeklo, „Prilozi za orijentalnu filologiju i istoriju jugoslovenskih naroda pod turskom vladavinom" 1952/1953, 3/4, s. 50. Zob. też L. Hadrovics, op. cit., s. 39.

${ }^{30}$ Zob. L. Hadrovics, op. cit., s. 40.

${ }^{31}$ Zob. M. Vukićević, Srpski jezik na Porti XV i XVI veka, "Zora” 1900, nr 5, s. 162-169.

${ }^{32}$ O. Zirojević, Srbija pod turskom, s. 78.

${ }^{33}$ A. Ivić, Neue cyrillische Urkunden aus den Wiener Archiven, ",Archiv für slavische Philologie" 1909, 30, s. 211.

${ }^{34}$ V. Jagić, Historija književnosti naroda hrvatskoga i srbskoga, knj. I: Staro doba, Zagreb 1867, s. 146. 
sów, co zdecydowanie ułatwiało inkorporację i funkcjonowanie podbitych terenów. Wśród zachowanych przez Turków osmańskich lokalnych struktur czy wzorców społeczno-kulturowych i prawno-politycznych można wymienić właśnie lokalne regulacje prawne, pochodzące z serbskiego systemu legislacyjnego sprzed podboju. Osmańskie kanuny z drugiej połowy XV w. i pierwszej połowy XVI w. obowiązujące w podbitej Serbii i Bośni (sandżak Smederevo, Kruševac, Klis, Bośnia i Hercegowina) zdradzają wpływy serbskiego prawa średniowiecznego. $Z$ powodu braku odpowiednich ekwiwalentów zaadaptowano na potrzeby osmańskiego systemu prawno-administracyjnego wiele terminów serbskiej (słowiańskiej) proweniencji (np.: baština, vojnuk, vlah, knez, primikur/primićur). Osmański system prawno-administracyjny przejął praktycznie bez żadnych zmian regulacje prawne despoty Stefana Lazarevicia z 1412 r. czy serbskie średniowieczne rozwiązania legislacyjne dotyczące statusu niektórych grup społecznych, takich jak społeczność Wołochów, która wcześniej funkcjonowała (na odmiennych zasadach) w państwie serbskim ${ }^{35}$.

W przypadku kultury duchowej wydaje się, że to ona stanowiła główną płaszczyznę alienacji. Termin „alienacja” uzasadnia i determinuje (związany do XVIII w. z mediewalnymi mechanizmami twórczymi) prawosławny charakter kultury serbskiej w tym okresie oraz ciągłość tradycji postbizantyńskiej. Jednak kultura jest systemem zhierarchizowanym oraz wielopłaszczyznowym, którego wewnętrzną strukturę regulują mechanizmy komunikacyjne, mogące generować szczególnie podatne na wpływy „miejsca”. Wraz z upadkiem serbskiej państwowości oraz zmniejszeniem instytucjonalnego nacisku Cerkwi i jej cenzury nastąpiła specyficzna preorientacja komunikacyjna, gwarantująca wzrost znaczenia przekazu oralnego (związanego z awansem kultury ludowej). Generalnie, należy podkreślić, iż ze względu na specyficzny fideizm prawosławia, ewokujący prymat objawienia nad poznaniem rozumowym czy obrzędu nad dogmatem, brak teologii spekulatywnej, teoretycznej literatury teologicznej, serbska tradycja religijna była szczególnie podatna na wpływy przekazu ludowego. Jednak to przede wszystkim warunki osmańskiego panowania przyczyniły się do rozwoju serbskiego prawosławia w kierunku ludowym $^{36}$. W przypadku serbskiego przekazu ustnego (szczególnie pieśni)

${ }^{35}$ E. Miljković, Ottoman Heritage in the Balkans: The Ottoman Empire in Serbia, Serbia in the Ottoman Empire, "Journal of Social Sciences" 2012, 27, s. 131-132. Zob. M. Begović, Tragovi našeg srednjovekovnog prava u turskim pravnim spomenicima, "Istorijski časopis” 1951/1952, 3, s. 71-74; E. Miljković, A. Krstić, Tragovi srpskog srednjovekovnog prava u ranim osmanskim kanunima i kanunnamama, w: Srednjovekovno pravo u ogledalu istorijskih izvora, Beograd 2009, s. 301-309.

${ }^{36}$ L. Hadrovics, op. cit., s. 19. 
można odnaleźć jego ślady w pismach autorów osmańskich, głównie konwertytów, np. u Suzi Çelebi († 1524) z Prizrenu, który wnosił do swych utworów elementy serbskich pieśni ${ }^{37}$. Oddalone od oficjalnej nauki teologicznej, wzbogacone elementami wierzeń pogańskich ludowe chrześcijaństwo (ludowy wariant prawosławia) oraz egzystujący "po drugiej stronie" granicy kulturowej, przesycony elementami szamanizmu ludowy islam wytworzyły charakterystyczną „próżnię”, która mogła zbliżyć osmańską kulturę islamską i serbską prawosławną na płaszczyźnie duchowej i konfesyjnej ${ }^{38}$.

Specyficznym, związanym z synkretyzmem religijnym, spoiwem pierwiastka islamskiego i chrześcijańskiego był fenomen kryptochrześcijaństwa. Kryptochrześcijanami byli przede wszystkim konwertyci, którzy formalnie przyjęli islam, lecz nadal potajemnie wyznawali chrześcijaństwo. Niektórzy różnicują fenomen kryptochrześcijaństwa i zjawisko tzw. niepełnej islamizacji; inni mówią raczej o etapach islamizacji czy „stopniach” kryptochrześcijaństwa ${ }^{39}$. Pierwsza wzmianka o tym zjawisku wśród Serbów pochodzi z 1568 r., kiedy jeden serbski żołnierz (deli, deliler) przyznał się francuskiemu posłannikowi na dworze sułtańskim w Adrianopolu, że jest ",serbskiej wiary i z serbskiego rodu”, żyje wśród Turków i udaje muzułmanina, ale od urodzenia całym sercem jest chrześcijaninem $^{40}$. Wpływ ludowego chrześcijaństwa na ludową wersję islamu widać przede wszystkim w takich zjawiskach, jak kult ikon, krzyża czy chrześcijańskich świętych (np. św. Jerzy sławiony jako Hizir, św. Mikołaj identyfikowany często z Sari Saltukiem) $)^{41}$. Inni bałkańscy muzułmanie chrzcili swoje dzieci' ${ }^{42}$ lub uznawali niektóre rytuały związane z Paschą czy Bożym Narodzeniem. Jednak w kontekście muzułmańskim część symboli i rytuałów chrześcijańskich uległa semantycznej transformacji3 ${ }^{3}$, implikującej wiarę w nadprzyrodzoną opiekę, magiczne działanie, ochronę przed demonem, chorobą (moc apotropeiczna). W kontekście lokalnym, na ziemiach serbskich niektórzy muzułmanie obchodzili slave (krsno ime) i uznawali kult św. Sawy ${ }^{44}$.

${ }^{37}$ O. Zirojević, Srbija pod turskom, s. 80.

${ }^{38}$ A. Željazkova, Razprostranenie na isljama v zapadnobalkanskite zemi pod osmanska vlast XV-XVIII vek, Sofija 1990, s. 142-143.

${ }^{39}$ O. Zirojević, Islamizacija na južnoslovenskom prostoru. Dvoverje, Beograd 2003, s. 5.

${ }^{40}$ S. Skendi, Crypto-Christianity in the Balkan Area under the Ottomans, "Slavic Review" 1967, t. 26, s. 242.

${ }^{41}$ O. Zirojević, Islamizacija, s. 39-42.

${ }^{42}$ Ibidem, s. 25-29.

${ }^{43}$ Zob. S. Vryonis, op. cit., s. 289.

${ }^{44}$ O. Zirojević, Sveti Sava i naši muslimani, w: Zbornik radova sa međunarodnog naučnog skupa: sveti Sava u srpskoj istoriji i tradiciji, Beograd 1998, s. 434-436. 
Specyficzna osmańska koncepcja pragmatycznej syntezy interkonfesyjnych wzorców, strategii, struktur zaczęła ulegać zmianom w drugiej połowie XVI w. Po podboju tradycyjnych centrów świata islamskiego w Egipcie i Syrii (1516/1517) Imperium Osmańskie zyskało bardziej konfesyjny charakter, ulegając silniejszej centralizacji oraz biurokratyzacji. Islam zaczął przenikać wszystkie sfery społeczno-politycznego życia w Imperium, a w armii zaczęto faworyzować element muzułmański. W okresie tym pojawiły się nowe wyzwania i zagrożenia dla władzy sułtańskiej oraz osmańskiego legitymizmu, co nabierało szczególnego znaczenia w kontekście eschatologicznego oczekiwania duchowej odnowy (w roku 1591/1592 upływało muzułmańskie millenium; tysiąc lat od Hidżry liczonej według systemu muzułmańskiego Anno Hegirae) i koncepcji stworzenia uniwersalnej monarchii islamskiej pod berłem osmańskiego sułtana. Jednak to przede wszystkim imperialna rywalizacja z monarchią Habsburgów w Europie i państwem Safawidów (dynastia ta nadała Iranowi szyicką tożsamość) w Azji pociągnęła za sobą potrzebę krystalizacji silnej (ortodoksyjnej) tożsamości religijnej, swoistej sunnityzacji, co z kolei prowadziło do konfesyjnej polaryzacji w Imperium Osmańskim ${ }^{45}$. Od drugiej połowy XVI w. coraz bardziej zmniejszała się (na co wpływ miała islamizacja) liczba chrześcijańskich Serbów w osmańskim systemie feudalno-administracyjnym i militarnym. Pogłębiający się kryzys feudalny i polityczny w Imperium Osmańskim stał się szczególnie widoczny w końcu XVI w. Prócz ogólnych zjawisk, takich jak wzrost obciążeń podatkowych, umocnienie pozycji feudałów i większy ucisk raji, kryzys ten miał też głębsze przyczyny. Anarchia spowodowana tureckimi porażkami (Lepanto w 1571; Sziszak w 1593), wojną austriacko-turecką (1593-1606), lokalnymi powstaniami, jak to w Banacie w $1594 \mathrm{r}^{46}$, doprowadziła do zastoju gospodarczego, głodu i epidemii, przez co opustoszała północna Serbia i rozwinął się ruch hajduków.

Na końcu warto wspomnieć o koncepcji synkretyzmu religijnego i kulturowego w okresie początkowym osmańskiego panowania. W związku z jej ostatnią krytyka, niektórzy obecnie rozumieją ją jako świadoma, promowaną przez niektóre grupy społeczne politykę religijnej czy kulturowej syntezy, która nie może być analizowana w izolacji od dyskursów związanych ze zjawiskiem antysynkretyzmu lub polityką podtrzymywania granic religijnych ${ }^{47}$. Dyskursy synkretyczne i antysynkretyczne pokrywają się częściowo z użytymi w tytule koncepcjami funkcjonowania płaszczyzn

${ }^{45}$ T. Krstić, Contested Conversions to Islam. Narratives of Religious Change in the Early Modern Ottoman Empire, Stanford 2011, s. 12-14.

${ }^{46}$ L. Hadrovics, op. cit., s. 104-105.

${ }^{47}$ T. Krstić, op. cit., s. 72-73. 
adaptacji oraz alienacji między kulturą serbską i osmańską. Synkretyzm związany był z różnorodnymi strategiami, pod powierzchnią których kryły się sprzeczne interesy niektórych grup, rywalizacja o władzę, wpływy i pozycję społeczną. Koncepcja osmańskiego synkretyzmu bowiem wywoływała niekiedy napięcia i opór konotujące dyskurs antysynkretyczny zarówno wewnątrz wspólnoty muzułmańskiej, jak i chrześcijańskiej. Przykładowo Konstantyn Mihailović w swej Kronice tureckiej, reprezentując dyskurs antysynkretyczny, negatywnie odnosi się do osmańskiej strategii inkorporacji chrześcijan do struktur społeczno-politycznych w celu przyspieszenia ich konwersji wyznaniowej. Dla K. Mihailovicia jest to jedna $\mathrm{z}$ metod osmańskiego podboju, w której upatruje wielkiego sukcesu Turków. Kreśląc obraz osmańskiej ekspansji, używa on charakterystycznej metafory morza, a przez zjawisko mieszania się wody słonej i słodkiej usiłuje oddać specyfikę osmańskiej idei synkretyzmu, będącej preludium islamizacji:

Tureckie rozmnażanie podobne jest morzu, ktorego nigdy nie przybywa ani ubywa [...]. Gdzie woda morska jest gruba a słona w niektorych krainach sol s niej dzałaja, a wszakoż wżdy nie przyczyniwszy czystej wody częściej słodkiej, sol być nie może; wody też wszytkie po świecie [się] plotąc, sam i tam słodkie bywają a dobre, a ku wszytkiem rzeczom potrzebne a pożyteczne, a gdy do morza wejda, a zmieszają się z wodą morska, wszytka dobrota a słodkość ich zginie i będzie jak inna woda morska gruba i słona [...]. A to się stawa wiele kroć rocznie: kilkonaście tysiąc przypędzą Chrześcijanow miedzy pogaństwo, a zmieszawszy [się] wszyscy się skażą jako i wody rzeczne w morzu ${ }^{48}$.

Immanentnie z synkretyzmem związane były takie zjawiska, jak konwersja wyznaniowa (islamizacja) oraz krystalizacja nowej tożsamości mieszkańców europejskiej części Imperium Osmańskiego - Rumelii i ich kultury. Nowa osmańska elita (głównie miejska) konstruowała swą tożsamość w kontekście napięć pomiędzy dyskursami synkretycznymi i antysynkretycznymi, w selektywny sposób wybierając religijne czy kulturowe elementy zarówno chrześcijańskiej, jak i muzułmańskiej proweniencji. Dużą część tej nowej, osmańskiej elity stanowili islamscy konwertyci, ale $\mathrm{w}$ początkowym okresie również chrześcijanie związani z osmańskim systemem feudalno-administracyjnym i społeczno-politycznym ${ }^{49}$. Kulturę serbską można analizować zatem albo w izolacji, albo w szerszym „rumelijskim” kontekście. Płaszczyzny adaptacji należy rozpatrywać jako wpływ kultury serbskiej na proces formowania nowej wspólnej kultury rozwijającej się pod berłem Osmanów.

\footnotetext{
${ }^{48}$ Pamiętniki Janczara, s. 159-160.

${ }^{49}$ T. Krstić, op. cit., s. 74.
} 


\section{BIBLIOGRAFIA}

Begović M., Tragovi našeg srednjovekovnog prava u turskim pravnim spomenicima, „Istorijski časopis" 1951/1952, 3.

Berger P.L., Luckmann T., Społeczne tworzenie rzeczywistości. Traktat z socjologii wiedzy, przeł. J. Niżnik, Warszawa 2010.

Czamańska I., Chrześcijańskie małżonki sułtanów tureckich. Małżeństwa polityczne w Imperium Osmańskim XIV i XV wieku, „Balcanica Posnaniensia. Acta et Studia” 2013, 20.

Golka M., Konstruowanie tożsamości-czynniki społeczno-kulturowe, „Ruch Prawniczy, Ekonomiczny i Socjologiczny" 2012, 74, 2.

Hadrovics L., Srpski narod i njegova Crkva pod turskom vlašću, przeł. M. Kovačević, Zagreb 2000.

Inalcik H., Imperium Osmańskie: epoka klasyczna 1300-1600, przeł. J. Hunia, Kraków 2006.

Inalcik H., Ottoman Methods of Conquest, "Studia Islamica” 1954, 2.

Inaldžik H., Od Stefana Dušana do osmanskog carstva. Hrišćanske spahije u Rumeliji u XV vijeku i njihovo porijeklo, „Prilozi za orijentalnu filologiju i istoriju jugoslovenskih naroda pod turskom vladavinom" 1952/1953, 3/4.

Ivić A., Neue cyrillische Urkunden aus den Wiener Archiven, „Archiv für slavische Philologie” $1909,30$.

Jagić V., Historija knjižeonosti naroda hrvatskoga i srpskoga, knj. I: Staro doba, Zagreb 1867.

Jelavich B., Historia Bałkanów - wiek XVIII i XIX, t. 1, przeł. J. Polak, K. Salawa, Kraków 2005.

Katić T., Serbia under the Ottoman Rule, „Österreichische Osthefte” 2005, 47.

Kłoskowska A., Kultury narodowe u korzeni, Warszawa 2005.

Kołodziejczyk D., The "Turkish yoke" revisited: the Ottoman Non-Muslim Subjects between Loyalty, Alienation and Riot, „Acta Poloniae Historica” 2006, 93.

Konstantin Filozof, Povest o slovima (Skazanije o pismeneh). Žitije despota Stefana Lazarevića, red. G. Jovanović, Beograd 1989.

Krstić T., Contested Conversions to Islam. Narratives of Religious Change in the Early Modern Ottoman Empire, Stanford 2011.

Kul M., Izkustvo i obščestvo v Bâlgarija prez tureckija period, przeł. R. Gradeva, Sofija 2002.

Kursar V., Non-Muslim Communal Divisions and Identities in the Early Modern Ottoman Balkans and the Millet System Theory, w: Power and Influence in South-Eastern Europe 16 $6^{\text {th }}$ $-19^{\text {th }}$ Century, eds. M. Baramova P. Mitev, I. Parev, V. Racheva, Berlin 2013.

Lowry H., The Nature of the Early Ottoman State, Albany 2003.

Miljković E., Krstić A., Tragovi srpskog srednjovekovnog prava u ranim osmanskim kanunima i kanunnamama, w: Srednjovekovno pravo u ogledalu istorijskih izvora, Beograd 2009, s. 301-309.

Miljković E., Ottoman Heritage in the Balkans: The Ottoman Empire in Serbia, Serbia in the Ottoman Empire, "Journal of Social Sciences" 2012, 27.

Miljković E., Who was Rich and who was Poor? Creation of the New Serbian "Elite" in the Serbian $15^{\text {th }}$ Century Society, "Beogradski istorijski glasnik” 2011, 2.

Pamiętniki Janczara czyli kronika turecka Konstantego z Ostrowicy napisana między r. 1496 a 1501, wyd. J. Łoś, Kraków 1912.

Petković S., Art and Patronage in Serbia during the Early Period of Ottoman Rule (1450-1600), w: Manzikert to Lepanto. The Byzantine World and the Turks 1071-1571, eds. A. Bryer, M. Ursinus, Birmingham 1985.

Pismo bosanskog kralja Stepana Tomaševića rimskom papi Piu II 1461 god., w: O etnogenezi Bošnjaka, red. H. Zoranić, Sarajevo 2009. 
Skendi S., Crypto-Christianity in the Balkan Area under the Ottomans, „Slavic Review” 1967, 26. Stavrianos L., The Balkans since 1453, New York 2000.

Sugar P., Southeastern Europe under Ottoman Rule 1354-1804, Seattle-London 1977.

Szacki J. Tradycja. Przeglad problematyki, Warszawa 1971.

Vasić M., Martolosi u jugoslovenskim zemljama pod turskom vladavinom, Sarajevo 2005.

Vryonis S., The Byzantine Legacy and Ottoman Forms, „Dumbarton Oaks Papers” 1969/1970, $23 / 24$.

Vukićević M., Srpski jezik na Porti XV i XVI veka, "Zora” 1900, 5.

Zirojević O., Islamizacija na južnoslovenskom prostoru. Dvoverje, Beograd 2003.

Zirojević O., Srbija pod turskom vlašću 1459-1804, Beograd 2009.

Zirojević O., Sveti Sava i naši muslimani, w: Zbornik radova sa međunarodnog naučnog skupa: sveti Sava u srpskoj istoriji i tradiciji, Beograd 1998.

Željazkova A., Razprostranenie na isljama $v$ zapadnobalkanskite zemi pod osmanska vlast XV-XVIII vek, Sofija 1990.

\section{ABSTRACT}

This work deals with Serbian culture and its various levels during the Ottoman period, especially from the second half of the $15^{\text {th }}$ century till the first half of the $16^{\text {th }}$ century. At that time, the Ottoman Empire had a specific pragmatic attitude towards its Christian subjects, absorbing their local practices, forms, cultural patterns. The Ottoman Empire adapted and incorporated them into its own feudal-administrative and politico-social structures, even if they were against Islam and sharia. The Ottoman Turks aimed at preserving cultural, political and social continuity. Moreover, this period was characterized with specific cultural and religious syncretism. However, this conception cannot be accepted without reservation and should be analyzed in relation to anti-syncretic tendencies. The main aim of our interest here is Serbian cultural influence on the process of construction of common, multi-ethnic, multi-confessional and multi-linguistic culture developed under the Ottomans in Rumelia. minority

Key words: Serbian culture, the Ottoman period, cultural impact, syncretism,

\section{NOTA O AUTORZE}

Paweł Dziadul - adiunkt Instytutu Filologii Słowiańskiej Uniwersytetu im. Adama Mickiewicza w Poznaniu. Studiował slawistykę i anglistykę. W centrum jego zainteresowań badawczych znajduje się piśmiennictwo słowiańskie prawosławnego średniowiecza (zarówno południowo-, jak i wschodniosłowiańskie), słowiańskie idee historiozoficzne, średniowieczna teologia polityczna, prawosławna myśl eschatologiczna. Autor monografii (W oczekiwaniu na Paruzję. Myśl eschatologiczna w prawosławnym piśmiennictwie stowiańskim do połowy XVI wieku) oraz licznych artykułów naukowych publikowanych w czasopismach polskich (np. „Przegląd Rusycystyczny”, „Studia Slavica”), zagranicznych („Die Welt der Slaven", "Zeitschrift für Slawistik") i tomach pokonferencyjnych. 